\title{
PENGARUH PENERAPAN OZON DARI DOUBLE DIELECTRIC BARIER DISCHARGE PLASMA UNTUK MENJAGA KESEGARAN JAMUR TIRAM PUTIH (PLEUROTUS OSTREATUS )
}

\author{
Intan Zahar'), Sutriono ${ }^{3)}$, Puryadi2), Syafrizal Hasibuan ${ }^{3)}$, Dian Puspita Sari ${ }^{4)}$ \\ 1)Jurusan Teknik Mesin, Universitas Asahan, Kisaran, Indonesia \\ 2) Jurusan Teknik Informatika, Universitas Cordova, NTB, Indonesia \\ 3)Jurusan Agroteknologi, Universitas Asahan, Kisaran, Indonesia \\ 4)Jurusan Budidaya Perairan, Universitas Asahan, Kisaran, Indonesia \\ Corresponding author : Intan Zahar \\ Email : intanzahar29@gmail.com
}

\begin{abstract}
ABSTRAK
Jamur tiram putih (Pleurotus ostreatus) merupakan salah satu produk makanan yang mudah mengalami kerusakan dan mempunyai waktu simpan pendek yaitu 1-2 hari. Produksi jamur tiram di Indonesia semakin tahun mengalami peningkatan sehingga dibutuhkan alternatif dalam menjaga umur simpan pada jamur. Salah satu teknologi yang masih terus berkembang adalah teknologi plasma ozon. Teknologi ini menggunakan plasma dingin untuk menghasilkan ozon $\left(\mathrm{O}_{3}\right)$. Baru-baru ini, beberapa peneliti telah mengembangkan teknologi ozon untuk mejaga umur simpan pada produk pasca panen hortikultura. Penelitian bertujuan untuk mengetahui pengaruh penyimpanan jamur tiram putih (Pleurotus ostreatus) dengan teknologi plasma ozon yang dibangkitkan dengan teknik Double Dielectric Barrier Discharge Plasma (DDBDP). Hasil kosentrasi ozon pada penelitian ini yaitu 65 ppm dengan kapasitas ozon sebesar $5.85 \mathrm{gram} / \mathrm{jam}$ pada flowrate $1.5(\mathrm{~L} / \mathrm{min})$ dan tegangan $9,5 \mathrm{kV}$. Ozon dialirkan ke dalam plastik yang berisi sampel jamur pada perlakuan $(5,10,15,20$ dan 25) menit. Berdasarkan hasil uji perubahan susut yang dilakukan, diperoleh perubahan susut tidak terlalu significant mengalami penurunan pada perlakuan ozone 20 menit dan 25 menit.
\end{abstract}

Kata kunci: Jamur tiram; ozone; Double Dielectric Barrier Discharge Plasma; produk hortikultura

\begin{abstract}
White oyster mushroom (Pleurotus ostreatus) is a food product that is easily damaged and has a short shelf life of 1-2 days. The production of oyster mushrooms in Indonesia is increasing every year so that an alternative is needed to maintain the shelf life of mushrooms. One technology that is still developing is plasma ozone technology. This technology uses cold plasma to produce ozone (O3). Recently, several researchers have developed ozone technology to maintain shelf life in post-harvest horticultural products. This study aims to determine the effect of storing white oyster mushrooms (Pleurotus ostreatus) with ozone plasma technology generated by the Double Dielectric Barrier Discharge Plasma (DDBDP) technique. The results of the ozone concentration in this study were $65 \mathrm{ppm}$ with an ozone capacity of $5.85 \mathrm{grams} /$ hour at a flowrate of $1.5(\mathrm{~L} / \mathrm{min})$ and a voltage of $9.5 \mathrm{Kv}$. Ozone was flowed into a plastic containing mushroom samples in the treatment $(5,10,15,20$ and 25$)$ minutes. Based on the results of the shrinkage change test carried out, it was found that the shrinkage change was not too significant and decreased in the 20 minute and 25 minute ozone treatment
\end{abstract}

Keywords: Oyster mushroom; ozone; Double Dielectric Barrier Discharge Plasma; horticultural products.

\section{PENDAHULUAN}

Jamur merupakan salah satu bahan makanan yang kaya akan protein, vitamin, mineral dan kandungan air serta memiliki kalori, lemak, gula dan kolestrol yang rendah (Vostrovsky, V. dan E. Jablonska, 2007). Jamur tiram (Pleurotus spp.) merupakan salah satu jamur yang paling sering dikonsumsi karena memiliki kandungan nutrisi tinggi dan memiliki rasa yang enak. Selain itu, jamur tiram dapat digunakan sebagai obat-obatan seperti mengobati migrant, hipertensi, radang sendi, kanker dan lainnya (Cheung, 2012). Namun, jamur termasuk bahan pangan yang mudah rusak dengan umur simpan selama 1-2 hari. Beberapa metode untuk mejaga kesegaran jamur telah banyak dilakukan yaitu dengan menggunakan metode pengeringan, Modified atmospheric packaging (MAP) dan lainnya (Muhandri,T. 2012; Oliveira et al., 2012). Metode yang paling sering digunakan adalah penyimpanan menggunakan kontrol suhu di dalam lemari pendingin. Namun, penyimpanan di dalam lemari pendingin tidak akan bisa 
menahan pembusukan, penyimpanan ini hanya mampu menahan penguapan air dari dalam jamur. Jamur tiram, seperti semua jenis sayur dan buah lainya, yang baru dipanen telah ditumbuhi oleh berbagai macam mikroorganisme. Mikroorganisme pembusuk pada buah dan sayuran merupakan faktor penyebab cepat rusak kesegaran dari sayur dan buah tersebut. Mikroorganisme penyebab masa simpan buah dan sayuran tidak bisa lama. Ini akan menyebabkan kerugian bagi petani, dan masyarakat pada umumnya metode tersebut masih memiliki beberapa kekurangan sehingga untuk mengatasi hal tersebut salah satu metode pangawetan yang dapat dilakukan adalah menggunakan teknologi plasma ozon.

Ozon merupakan pengoksidasi kuat sebagai antimikroba, agen bakterisida dan bersifat disinfektan yang dapat digunakan untuk memastikan keamanan mikrobiologis pada makanan (Khandre et al, 2001). Food and Drug Administration (FDA) telah menyetujui perlakuan ozon untuk penyimpanan makanan dalam fase gas dan cair (Federal Register, 2001). Salah satu teknik untuk menghasilkan ozon adalah menggunakan Dielectric Barrier Discharge Plasma (DBDP) dengan memanfaatkan tegangan tinggi (Nur, 2011). Beberapa peneliti telah menggunakan ozon untuk pengawetan (menjaga kesegaran) pada makanan seperti pengawetan pada sayuran. Ade ika susan, dkk dan Eva sasmita, 2018 melaporkan bahwa ozon dapat memperpanjang umur simpan pada sayuran dengan menghambat pertumbuhan mikroba yang menyebabkan pembusukan pada sayuran.

Di Indonesia pengembangan penelitian perlakuan ozon terhadap produk Hortikultura dikembangkan oleh Center Plasma research Universitas Diponegoro. Pusat penelitian plasma tersebut telah menghasilkan konsep standard nasional dan dijadikan standard dengan nomor SNI 8759:2019 tentang Alat penyimpanan produk hortikultura pascapanen menggunakan teknologi ozon - Syarat mutu dan metode uji.

Penelitian yang akan dilakukan adalah penyimpanan jamur tiram putih (Pleurotus ostreatus) dengan teknologi plasma ozon yang dibangkitkan dengan teknik Double Dielectric Barrier Discharge Plasma (DDBDP). Penelitian ini untuk mendapatkan parameter fisis seperti tegangan, kosentrasi Ozon, kapasitas ozon dari generator Double Dielectric Barier Discharge Plasma dan untuk membandingkan hasil penyimpanan dari perlakuan ozon dengan tanpa perlakuan (kontrol). Parameterparameter fisis ini diperlukan untuk mendapatkan nilai optimum konsentrasi ozon yang tepat diperlukan untuk penyimpanan jamur tiram. Penelitian ini adalah penelitian pemula dengan Tingkat Kesiapan Teknologi (1-3), dan akan diteruskan ke TKT yang lebih tinggi. Diharapkan pada akhirnya nanti menghasilkan teknologi khusus untuk penyimpanan jamur tiram. Hasil penelitian ini diharapkan dapat memberikan tambahan rujukan bagi penelitian berikutnya yang terkait dengan perlakuan ozon dan penyimpanan jamur tiram putih (Pleurotus ostreatus).

\section{METODE PENELITIAN}

Tahapan pada penelitian ini yaitu diawali dengan karakterisasi generator ozon menggunakan Double Dielectric Barrier Discharge Plasma (DDBDP).

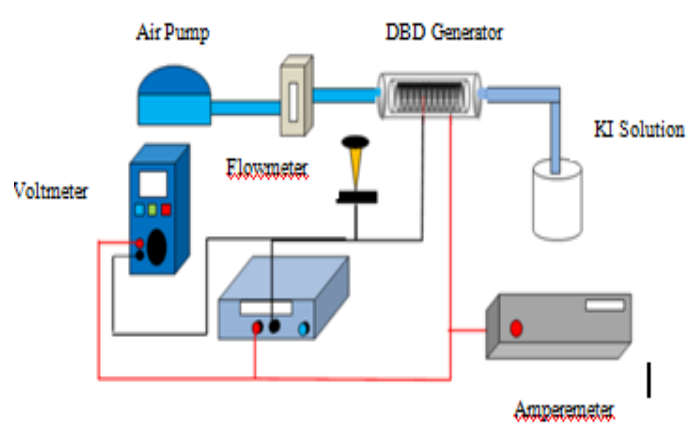

Gambar 1. Karakteristik reactor ozone (intan.Z., dkk,2019)

Kosentrasi dan kapasitas ozon terbaik digunakan dalam melakukan treatment terhadap jamur tiram putih. Jamur Tiram Putih (Pleurotus ostreatus), diambil langsung dari tempat Budidaya Jamur Tiram. Jamur dimasukkan dalam Box Plastik ukuran $17 \times 12$ $x 5.5 \mathrm{~cm}$, yang digunakan sebagai tempat jamur. Jamur kemudian dibagi menjadi 3 kelompok yaitu

1. Sampel tanpa perlakuan (Kontrol)

2. Sampel diletakkan dalam wadah yang di injeksikan ozon selama 5 , 10, 15, 20 dan 25 menit di tutup plastik tanpa respirasi

3. Sampel diletakkan dalam wadah yang di injeksikan ozon selama 5 , 10, 15, 20 dan 25 menit di tutup plastik dengan respirasi

Masing-masing perlakuan jamur di simpan dalam penyimpanan dingin selama 6 hari. Pemberian ozon dilakukan satu kali dan dilakukan pengujian dengan menguji berat dan melihat perubahan warna jamur setiap 2 hari sekali. 


\section{HASIL DAN PEMBAHASAN}

Karakteristik tegangan dan kosentrasi

Tegangan yang digunakan untuk membangkitkan plasma pada reaktor Double Dielectric Barier Discharge yaitu dilakukan dengan variasi tegangan dari tegangan $5,5 \mathrm{kV}$ dengan skala $0,5 \mathrm{kV}$ hingga tegangan $9,5 \mathrm{kV}$. Tegangan yang dihasilkan digunakan untuk melihat kosentrasi ozon yang dihasilkan dari reaktor. Perhitungan kosentrasi ozon dengan metode titrasi yaitu menggunakan Larutan KI (Kalium lodida) yang berubah warna (Larutan $\mathrm{KI}$ dan Ozon) kemudian dititrasi mengguakan larutan $\mathrm{Na}_{2} \mathrm{~S}_{2} \mathrm{O}_{3}$ hingga Larutan $\mathrm{KI}$ menjadi tak bewarna, volume tetesan titrasi kemudian dicatat dan disibsitusikan kedalam rumusan berikut (Suraidin, 2016)

$$
\mathrm{C}_{\text {ozon }}=\frac{M r O_{3} \cdot V \cdot N}{V_{\text {udara }} \cdot \text { e.t }}
$$

Keterangan :

$$
\begin{aligned}
& \mathrm{C}_{\text {ozon }}=\text { Kosentrasi Ozon (ppm) } \\
& \mathrm{Mr}=\text { Massa molekul relative ozone (48 (gram } \\
& \mathrm{mol}^{-1} \text { ) } \\
& \mathrm{V}=\text { Volume tetesan } \mathrm{Na}_{2} \mathrm{~S}_{2} \mathrm{O}_{3} \text { (ml unit) } \\
& \mathrm{N}=\text { normalitas } \mathrm{Na}_{2} \mathrm{~S}_{2} \mathrm{O}_{3} \text { (molar) } \\
& \text { Vudara = Laju alir (udara bebas) }(\mathrm{L} / \text { menit) } \\
& \mathrm{t}=\text { Waktu ozone } \\
& \mathrm{e} \quad=\text { Konstanta massa elektron }
\end{aligned}
$$

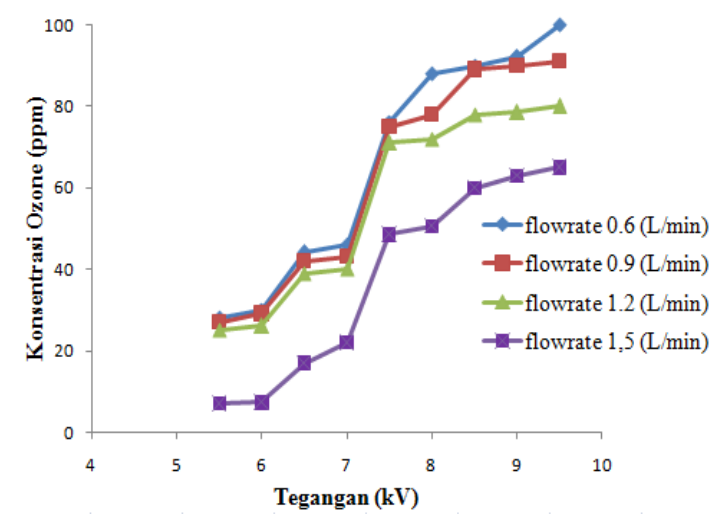

Gambar 2. Grafik tegangan sebagai fungsi kosentrasi untuk beberapa flowrate.

Gambar 1 menunjukkan hubungan tegangan sebagai fungsi kosentrasi ozon. Hasil yang didapatkan ozon mulai terbentuk pada tegangan $5,5 \mathrm{kV}$. Semakin besar tegangan yang diberikan pada reaktor maka kosentrasi ozon semakin meningkat pada variasi flowrate. Pada tegangan tetap, flowrate $0,6(\mathrm{~L} / \mathrm{min})$ menghasilkan kosentrasi ozon yang lebih tinggi dibandingkan dengan flowrate yang lebih tinggi. Hasil kosentrasi ozon yang lebih tinggi adalah $100 \mathrm{ppm}$ pada tegangan $9,5 \mathrm{kV}$ dan flowrate 0,6 (L/min). Kosentrasi ozon yang teendah yaitu pada flowrate 1,5 (L/menit) pada tegangan 9,5 $\mathrm{kV}$ dengan kosentrasi ozon sebesar $65 \mathrm{ppm}$.
Hal ini dapat dijelaskan karena waktu tinggal gas dalam reaktor semakin lama yang memungkinkan proses tumbukan dan ionisasi semakin banyak terjadi. Selain itu, tegangan juga dapat mempengaruhi dimana peningkatan tegangan dapat menghasilkan medan listrik yang cukup tinggi sehingga dapat mempercepat elektron, molekul atau ion yang masuk dalam tabrakan non-elastis.

\section{Kapasitas Produksi Ozone}

Hasil data pengukuran kapasitas ozon sebagai fungsi flowrate pada tegangan $5,5 \mathrm{kV}-$ $9,5 \mathrm{kV}$. Semakin besar tegangan yang diberikan pada reactor ozone maka semakin besar kapasitas ozone dengan flowrate $(0,6 ; 0,9 ; 1,2$; dan $1,5 \mathrm{l} /$ menit) seperti terlihat pada gambar 3 dibawah ini.

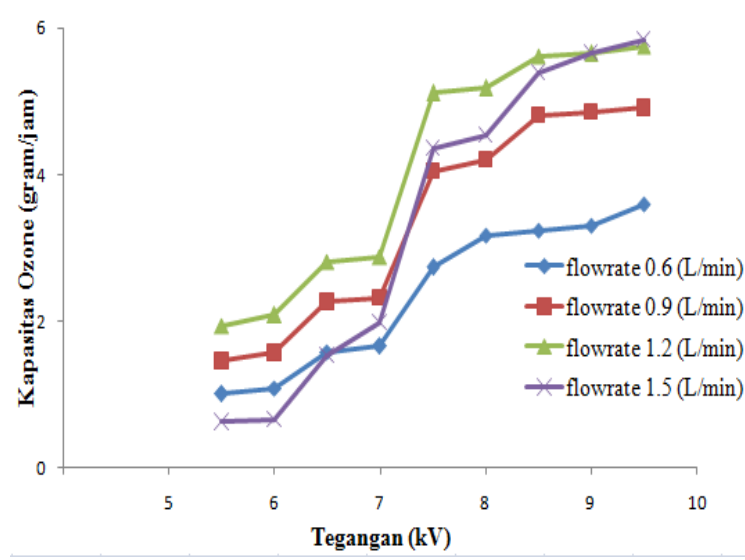

Gambar 2. Grafik kapasitas ozone sebagai fungsi tegangan.

Kapasitas ozon adalah banyaknya ozon dalam waktu tertentu dengan mengalirkan flowrate (Nur, et al., 2017). Kapasitas ozon dapat dihitung dengan hasil kali antara kosentrasi (gram/L) dengan laju alir udara (L/jam). Gambar 2 menunjukkan kapasitas ozon dalam berbagai flowrate sebaga fungsi tegangan. Pada tegangan tetap terlihat bahwa kapasitas ozon meningkat pada flowrate 1,5 (L/min) terhadap tegangan $9,5 \mathrm{kV}$ dengan nilai kapasitas ozon sebesar 5,85 gram/jam. Sedangkan kapasitas ozon terendah yaitu pada flowrate 0,6 (L/min) dengan nilai kapasitas sebesar $3.6 \mathrm{gram} / \mathrm{jam}$.

\section{Treatment Ozone pada Jamur Tiram}

Gas ozon di injeksikan ke dalam plastik yang berisi jamur tiram putih (Pleurotus ostreatus) selama $0,5,10,15,20$ dan 25 menit dengan masing-masing berat jamur sebesar 200 gram. Kosentrasi yang digunakan untuk perlakuan ozon pada penelitian ini yaitu $65 \mathrm{ppm}$ dengan kapasitas ozon sebesar 5.85 gram/jam pada flowrate $1.5(\mathrm{~L} / \mathrm{min})$ dan tegangan $9,5 \mathrm{Kv}$. Masing-masing perlakuan pada sampel 
dimasukkan ke dalam plastik tanpa respirasi untuk selanjutnya di simpan dalam pendingin. Pemberian ozon dilakukan satu kali dan dilakukan pengujian dengan menguji berat dan melihat perubahan warna jamur setiap 2 hari sekali dengan mengambil satu sampel sebagai bahan pengamatan.

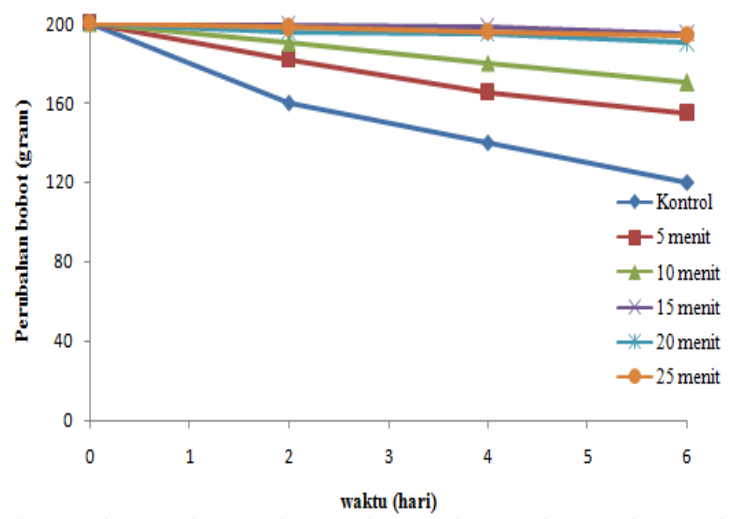

Gambar 3. Perubahan bobot pada jamur

Gambar 3 merupakan grafik perubahan bobot yang terjadi pada jamur terhadap fungsi waktu. Hasil tersebut menunjukkan semakin lama penyimpanan jamur maka semakin rendah nilai perubahan bobot pada perlakuan kontrol maupun perlakuan ozon (5, 10, 15, 20 dan 25) menit. Hal ini juga dilakukan oleh (I. Escriche, dkk.,2014) yang menunjukkan perubahan susut bobot yang terjadi selama 7 hari. Secara umum hasil perlakuan ozon selalu lebih baik dibandingkan dengan kontrol. Perlakuan kontrol pada hari ke enam mengalami perubahan susut sebesar 120 gram sedangkan jamur yang diberi perlakuan ozon selama 20 dan 25 menit tidak begitu signifikan mengalami perubahan bobot yaitu sebesar 190 dan 192 gram. Hasil ini juga di dukung dengan perubahan tampak warna pada permukaan jamur.

Tabel 1. Perubahan warna jamur pada setiap

\begin{tabular}{|c|c|c|}
\hline $\begin{array}{c}\text { Perlaku } \\
\text { an }\end{array}$ & $\begin{array}{l}\text { Hari } \\
\text { ke-2 }\end{array}$ & $\begin{array}{l}\text { Hari } \\
\text { ke-6 }\end{array}$ \\
\hline Kontrol & & \\
\hline $\begin{array}{l}5 \text { Menit } \\
\text { Ozone }\end{array}$ & & \\
\hline
\end{tabular}

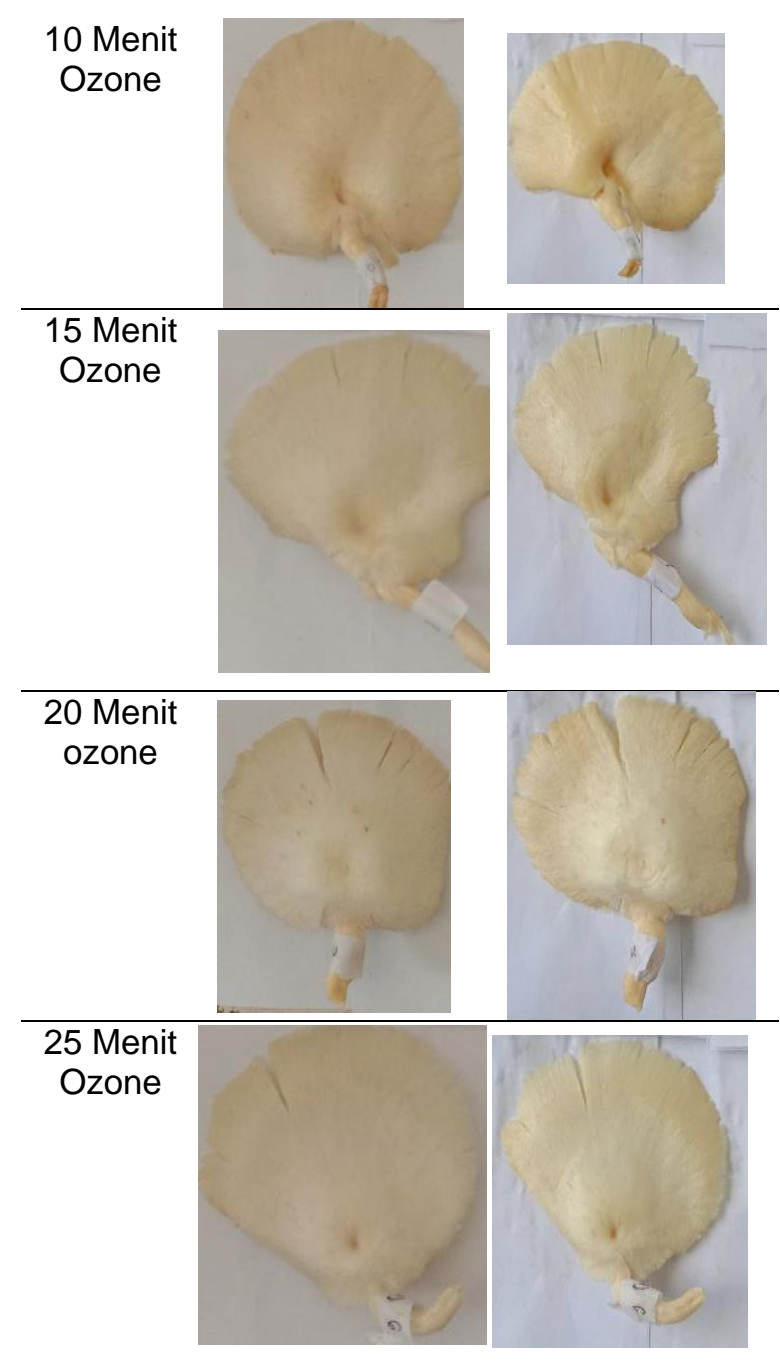

Tabel 1 menunjukkan perubahan warna pada jamur untuk setiap perlakuan. Terlihat bahwa, untuk perlakuan kontrol dan perlakuan ozone selama (5 dan 10) menit mengalami perubahan warna menjadi kecokelatan. Sedangkan pada perlakuan ozone $(15,20$ dan 25) menit tidak mengalami perubahan warna. Selanjutnya pada hari ke 6 untuk perlakuan ozon 20 dan 25 menit perubahan warna yang terjadi tidak terlalu signifikant dibandingkan dengan kontrol.

\section{SIMPULAN DAN SARAN}

Hasil kosentrasi ozon pada penelitian ini yaitu 65 ppm dengan kapasitas ozon sebesar $5.85 \mathrm{gram} / \mathrm{jam}$ pada flowrate 1.5 (L/min) dan tegangan 9,5 Kv. Ozon dialirkan ke dalam plastik yang berisi sampel jamur pada perlakuan $(5,10,15,20$ dan 25) menit. Berdasarkan hasil uji perubahan susut yang dilakukan, diperoleh perubahan susut tidak terlalu signifikant mengalami penurunan pada perlakuan ozone 20 menit dan 25 menit. Penelitian selanjutnya dapat dilakukan 
pengujian lebih lanjut terkait dengan kadar proksimat pada jamur tiram.

\section{DAFTAR RUJUKAN}

Sasmita. E., Eko. Y., Maryam. R., Ade., I., S, (2018), Effects of ozone-washing in a series of ozonation methods for inhibition of total microbial growth in some varieties of chili (Capsicum annuum L.), IOP Conference Series MaterialScience and Engineering 434:012020

Cheung, F., (2012). Plant genetics: The lingzhi mushroom genome. Nature China.

Khadre, M. A., Yousef, A.E., Kim, J.G., (2001), Microbiological Aspect of Ozone Application in Food, Journal of Food Sience 66, No. 99. Pp 1-9

Ika, A. S., Eko.Y., Fajar.A., Eva.S., (2018), Ozone application to extend shelf life of vegetables by microbial growth inhibition, MATEC Web of Conference 197(5);02004

Nur, Muhammad., (2011), Fisika Plasma dan Aplikasi, Undip press, Universitas Diponegoro, Semarang.

Nur, Muhammad., Susan, I. K., Muhlisin, Z., Arianto, F., Kinandana, W.A., Nurhasanah, L., Sumariyah, S., Wibawa. J.P., Gunawan, G., Usman, A. (2017). Evaluation of Novel Integrated Dielectric Barrier Discharge Plasma as Ozone Generator, Bulletin of Chemical Reaction Engineering \& Catalysis, pp 24-31

Vostrovsky, V. and E. Jablonska, (2007). Mushroom growing with informationsupport as opportunity for the developing countries. Agricultura Tropica et Subtropica, 4(3), 120-125 